\title{
GAMBARAN PERILAKU MAHASISWA BERISIKO TERTULAR COVID-19 SELAMA PANDEMI DI KOTA KENDARI
}

\author{
Description of College Student Behavior Who are at Risk Contacting Covid-19 During The \\ Pandemic in Kendari City
}

Fitri Yanti, Komang Ayi Sukma

Program Studi Sarjana Kesehatan Masyarakat

Universitas Mandala Waluya

(fitrililiyanti@gmail.com, 085342733542)

\begin{abstract}
ABSTRAK
Di awal tahun 2020, dunia digemparkan dengan merebaknya corona virus jenis baru yaitu Corona Virus Disease 2019 (COVID-19). Pemerintah menghimbau kepada masyarakat untuk menerapkan protokol kesehatan untuk mencegah penularan COVID-19. Namun, pada kenyataannya masih ada masyarakat yang tidak mengindahkan himbauan tersebut termasuk mahasiswa. Penelitian ini bertujuan untuk mengetahui gambaran perilaku mahasiswa selama pandemi COVID-19 di Kota Kendari. Jenis Penelitian ini adalah penelitian kuantitatif dengan desain penelitian Deskriptif. Sampel penelitian berjumlah 2.039 responden. Analisis data menggunakan analisis univariat dengan tabel distribusi frekuensi. Hasil penelitian menunjukkan bahwa tingkat pengetahuan responden terbanyak adalah kategori cukup yaitu 1.430 responden $(70,1 \%)$, sikap responden terbanyak adalah sikap positif yaitu 1.440 responden $(70,6 \%)$, dan tindakan berisiko responden terbanyak adalah tindakan berisiko rendah yaitu 1.523 responden (74,7\%). Persentase perilaku berisiko tertular COVID-19 yaitu 18,7\% masih bepergian ke tempat ramai, 46,5 \% pulang ke kampung masing-masing, 16,7 tidak menggunakan masker, 6,4\% tidak mencuci tangan pakai sabun/handsanitizer, dan 10,9\% yang bepergian ke daerah yang terdapat kasus COVID-19. Kesimpulan dari penelitian ini sebagian besar mahasiswa di Kota Kendari telah memahami dan mengamalkan berbagai pengetahuan dan perilaku terkait pandemi COVID-19. Diharapkan agar mahasiswa dan juga masyarakat Kota Kendari dapat meningkatkan perilaku hidup bersih dan sehat dan juga patuh dalam menerapkan protokol kesehatan.
\end{abstract}

Kata kunci: COVID-19, perilaku, pengetahuan, sikap, tindakan

\section{ABSTRACT}

At the beginning of 2020, the world was shocked by the outbreak of a new type of coronavirus, Coronavirus Disease 2019 (COVID-19). The government appeal to the public to implement health protocols to prevent the transmission of COVID-19. However, there are still many people who heed this appeal include colleger. The purpose of this research is to find out the description of colleger behavior during the COVID-19 pandemic in Kendari City. This type of research is quantitative research with descriptive design study. The sample of the research is 2.039 respondents. Data analysis using univariate analysis with distribution frequency tables. The result of the level of knowledge for the most respondents was enough category amounting to 1.430 respondent $(70,1 \%)$, the attitude of the most respondents was positive category amounting to 1.440 respondent $(70,6 \%)$, and the risk activities of the most respondents were low-risk action amounting to 1.523 respondent (74,7\%). The percentage of behavior at risk of contracting COVID-19, namely 18,7\% still traveling to crowded places, 46,5\% returning to their respective villages, $16,7 \%$ not using masks, $6,4 \%$ not washing hands with soap/handsanitizer, and 10,9\% who traveled to areas with COVID-19 cases. The conclusion of this study was mostly college students in Kendari City have understood and implemented various knowledge and behaviors about COVID-19. Suggested for college students and community of Kendari City to improve their hygiene and healthy living behavior and then obey to the application of health protocols.

Keywords: COVID-19, behavior, knowledge, attitude, action 


\section{PENDAHULUAN}

Pada awal tahun 2020, masyarakat digemparkan dengan munculnya jenis corona virus baru yang mengakibatkan kepanikan dan mengancam kesehatan masyarakat secara umum. WHO (World Health Organization) menetapkan COVID-19 sebagai pandemi yang menunjukkan keadaan darurat kesehatan masyarakat yang menjadi perhatian dunia internasional di awal tahun 2020. ${ }^{1}$ Corona

Virus Disease 2019 atau COVID-19 merupakan penyakit menular yang disebabkan oleh virus corona jenis baru yang menyebabkan sindrom pernapasan akut. Diketahui asal mula virus ini berasal dari Kota Wuhan, Tiongkok yang ditemukan pada akhir Desember 2019. ${ }^{2}$ Sampai saat ini, terdapat 216 negara telah dikonfimasi terjangkit virus ini. Terhitung sejak terkonfirmasinya COVID-19 hingga 01 November 2020 sebanyak 46.359.803 orang terinfeksi virus corona, 1.199.640 orang meninggal dunia, dan 33.469 orang telah dinyatakan sembuh. ${ }^{3}$

Kasus COVID-19 di Indonesia memiliki prevalensi yang cukup tinggi. Kasus terkonformasi pertama kali di Indonesia pada tanggal 2 Maret 2020, hanya 2 penderita. Namun, hingga sekarang sudah mencapai ribuan dan menjadikan Indonesia berada diperingkat pertama negara terjangkit COVID19 di wilayah Asia Tenggara. Berdasarkan data Gugus Tugas COVID-19 Republik Indonesia per tanggal 01 November 2020 berjumlah 412.784 orang terinfeksi, 13.943 orang meninggal dunia, dan pasien yang dinyatakan sembuh sebesar 341.942. Provinsi Sulawesi Tenggara menempati urutan ke-17 di
Indonesia dalam jumlah pasien positif COVID-19, yaitu sebesar 5.070, sedangkan Kota Kendari menduduki posisi teratas di Provinsi Sulawesi Tenggara dalam jumlah pasien positif COVID-19 yaitu sebesar 2.672 orang. ${ }^{4}$ Hal ini jumlahnya meningkat tajam bila dibandingkan awal pandemi yang hanya berjumlah 3 orang. Berdasarkan data tersebut, maka semua pihak terkait, baik pemerintah maupun masyarakat harus terus melakukan tindakan deteksi dini dan pencegahan penyebaran COVID-19, guna menurunkan jumlah kasus COVID-19.

Peningkatan kasus COVID-19 yang terjadi di masyarakat didukung oleh proses penyebaran virus yang cepat. Proses penularan antara manusia dapat terjadi melalui kontak erat dengan pasien terinfeksi COVID-19, yang disebabkan pengeluaran droplet yang mengandung virus SARS-CoV-2 ke udara oleh pasien terinfeksi pada saat batuk maupun bersin. ${ }^{5}$ Kesadaran masyarakat untuk menjaga kesehatan mereka serta kedisiplinan dalam penerapan physical distancing menjadi faktor utama keberhasilan memutus rantai penularan. Para peneliti sedang berusaha menemukan pengobatan yang paling tepat untuk penanggulangan virus ini, namun sampai saat ini belum ditemukan formula yang paling tepat. ${ }^{6}$

Pengendalian penyebaran virus corona harus dilaksanakan secara komprehensif dan terkoordinasi antara pemerintah dan masyarakat. Pemerintah membuat regulasi yang tepat agar masyarakat mampu menaati regulasi tersebut. Dalam bidang kesehatan diperlukan promosi kesehatan, agar 
masyarakat dapat memahami dan mau menerapkan prosedur kesehatan untuk memutus rantai penularan. Pengendalian COVID-19 dapat berjalan dengan baik jika didukung oleh pengetahuan dan sikap yang baik terkait pencehagan COVID-19. Hal ini akan mendorong perilaku pencegahan yang baik sebagai solusi pencegahan penularan COVID-19. Solusi untuk menekan laju penularan adalah mengikuti prosedur pencegahan dengan cara sering menuci tangan dengan air dan sabun, menjaga jarak minimal 1 meter, menutup mulut saat batuk/bersin, serta menjaga jarak secara fisik tanpa melakukan perjalanan yang tidak perlu serta menjauhi kerumunan masa. ${ }^{7}$

Pembatasan aktivitas tidak hanya dilakukan di rumah ibadah, tempat-tempat umum, melainkan juga di sekolah-sekolah tidak terkecuali kampus-kampus (perguruan tinggi). Pembatasan aktivitas pada perguruan tinggi mendorong pemerintah untuk memberlakukan kebijakan kuliah daring (dalam jaringan) atau belajar system online. Dengan diberlakukannya kebijakan ini, maka secara tidak langsung membuat para pelajar/ mahasiswa yang berada di Kota Kendari dan berasal dari daerah memutuskan kembali ke daerah masing-masing. Arus balik mahasiswa ke daerah otomatis memiliki potensi tertular COVID-19. Hal ini memperbesar potensi peularan Covid-19 jika tidak mematuhi protokol kesehatan seperti memakai masker, mencuci tangan pakai sabun, dan menjaga jarak. Sehingga mahasiswa menjadi salah satu populasi berisiko tertular Covid-19. Risiko penularan COVID-19 pada mahasiswa dapat diminimalisir jika mahasiswa memiliki pengetahuan, sikap dan tindakan yang baik terkait COVID-19. Oleh karena itu penelitian ini bertujuan untuk mengetahui gambaran perilaku mahasiswa selama pandemi COVID19 sehingga dapat dijadikan pedoman atau dasar dalam penyusunan program oleh pemerintah daerah dalam menurunkan kasus penularan COVID-19.

\section{BAHAN DAN METODE}

Penelitian ini merupakan jenis penelitian kuantitatif dengan desain penelitian deskriptif. Penelitian telah dilakukan pada bulan AprilNovember di Kota Kendari. Populasi dalam penelitian adalah seluruh mahasiswa di Kota Kendari, dengan jumlah sampel sebanyak 2.039 orang. Pengambilan sampel dilakukan dengan menggunakan teknik Snowball Sampling. Pengumpulan data dilakukan dengan menggunakan kuesioner online dalam bentuk Google Form yang disebarkan melalui media sosial. Hasil penelitian dianalisis secara univariat (deskriptif) untuk mengetahui gambaran perilaku mahasiswa berisiko tertular COVID-19 selama pandemi di Kota Kendari. Penyajian data dilakukan dalam bentuk tabel distribusi frekuensi dan grafik.

\section{HASIL}

Karakteristik responden meliputi jenis kelamin, kelompok umur, tempat tinggal, asal daerah, dan status pernikahan. Distribusi frekuensi responden berdasarkan jenis kelamin pada Tabel 1 menunjukkan bahwa dari 2.039 responden, 1.389 responden $(68,1 \%)$ 
diantaranya berjenis kelamin perempuan dan 650 responden $(31,9 \%)$ berjenis kelamin lakilaki.

\section{Tabel 1. Karakteristrik Responden}

\begin{tabular}{|c|c|c|}
\hline Karakteristrik & $\mathbf{N}$ & $\%$ \\
\hline \multicolumn{3}{|l|}{ Jenis Kelamin } \\
\hline Laki-laki & 650 & 31,9 \\
\hline Perempuan & 1.389 & 68,1 \\
\hline \multicolumn{3}{|l|}{ Kelompok Umur } \\
\hline 16-20 Tahun & 1.324 & 64,9 \\
\hline 21-25Tahun & 670 & 32,9 \\
\hline 26-30 Tahun & 34 & 1,7 \\
\hline 31-35 Tahun & 8 & 0,4 \\
\hline 36-40 Tahun & 3 & 0,1 \\
\hline \multicolumn{3}{|l|}{ Tempat Tinggal } \\
\hline Kab. Kolaka & 91 & 4,5 \\
\hline Kab. Konawe & 21 & 1,0 \\
\hline Kab. Muna & 21 & 1,0 \\
\hline Kota Bau-Bau & 65 & 3,2 \\
\hline Kota Kendari & 1.622 & 79,5 \\
\hline $\begin{array}{l}\text { Luar Sulawesi } \\
\text { Tenggara }\end{array}$ & 219 & 10,7 \\
\hline \multicolumn{3}{|l|}{ Asal Daerah } \\
\hline Bau-Bau & 211 & 10,3 \\
\hline Kab. Bombana & 49 & 2,4 \\
\hline Kab. Buton Utara & 39 & 1,9 \\
\hline Kab. Kolaka & 188 & 9,2 \\
\hline Kab. Kolaka timur & 1 & 0,0 \\
\hline Kab. Kolaka Timur & 39 & 1,9 \\
\hline Kab. Kolaka Utara & 16 & 0,8 \\
\hline Kab. Konawe & 243 & 11,9 \\
\hline $\begin{array}{l}\text { Kab. Konawe } \\
\text { Kepulauan }\end{array}$ & 33 & 1,6 \\
\hline $\begin{array}{l}\text { Kab. Konawe } \\
\text { Selatan }\end{array}$ & 109 & 5,3 \\
\hline Kab. Konawe Utara & 31 & 1,5 \\
\hline $\begin{array}{c}\text { Kab. Muna/Muna } \\
\text { Barat }\end{array}$ & 179 & 8,8 \\
\hline Kab. Wakatobi & 67 & 3,3 \\
\hline Kendari & 651 & 31,9 \\
\hline $\begin{array}{c}\text { Luar Sulawesi } \\
\text { Tenggara }\end{array}$ & 183 & 9,0 \\
\hline Jumlah & 2.039 & 100,0 \\
\hline
\end{tabular}

Sumber: Data Primer, 2020

Distribusi frekuensi responden berdasarkan kelompok umur pada Tabel 1 menunjukkan bahwa, kelompok umur terbanyak adalah kelompok umur 16-20 Tahun yaitu 1.324 responden $(64,9 \%)$ dan kelompok umur yang paling sedikit adalah kelompok umur 36-40 Tahun yaitu 3 responden $(0,1 \%)$. Distribusi frekuensi responden berdasarkan tempat tinggal pada Tabel 1 menunjukkan bahwa, responden paling banyak bertempat tinggal di Kota Kendari yaitu 1.622 responden (79,5\%) dan paling sedikit bertempat tinggal di Kabupaten Konawe dan Kabupaten Muna yaitu 21 responden $(1,0 \%)$.

Distribusi frekuensi responden berdasarkan asal daerah pada Tabel 1 menunjukkan bahwa, responden paling banyak berasal dari Kota Kendari yaitu 651 responden $(31,9 \%)$ dan paling sedikit berasal dari daerah Kabupaten Kolaka Timur yaitu 1 responden $(0,04 \%)$. Distribusi frekuensi responden berdasarkan status pernikahan pada Tabel 1 menunjukkan bahwa dari 2039 responden, 1.971 responden $(96,7 \%)$ diantaranya berstatus belum menikah dan 68 responden $(3,3 \%)$ diantaranya berstatus sudah menikah.

Distribusi frekuensi responden berdasarkan tingkat pengetahuan pada Tabel 2 menunjukkan bahwa dari 2.039 responden, 609 responden $(29,9 \%)$ diantaranya memiliki tingkat pengetahuan kategori kurang dan 1.430 responden $(70,1 \%)$ diantaranya memiliki tingkat pengetahuan kategori cukup. Distribusi frekuensi responden berdasarkan sikap pada Tabel 2 menunjukkan bahwa dari 2.039 responden, 599 responden $(29,4 \%)$ diantaranya memiliki sikap negatif dan 1.440 responden $(70,6 \%)$ diantaranya memiliki sikap positif. Distribusi frekuensi responden berdasarkan tindakan pada Tabel 2 menunjukkan bahwa dari 2.039 responden, 516 responden $(25,3 \%)$ diantaranya berisiko tinggi tertular COVID-19 
dan 1.523 responden $(74,7 \%)$ diantaranya berisiko rendah tertular COVID-19.

Tabel 2. Distribusi Frekuensi Reponden

Berdasarkan Pengetahuan, sikap dan Tindakan terkait COVID-19

\begin{tabular}{crr}
\hline Variabel & N & \% \\
\hline Pengetahuan & & \\
Kurang & 609 & 29,9 \\
Cukup & 1.430 & 70,1 \\
\hline Sikap & & \\
Negatif & 599 & 29,4 \\
Positif & 1.440 & 70,6 \\
\hline Tindakan & & \\
Berisiko Tinggi & 516 & 25,3 \\
Berisiko Rendah & 1.523 & 74,7 \\
\hline Jumlah & $\mathbf{2 . 0 3 9}$ & $\mathbf{1 0 0 , 0}$ \\
\hline
\end{tabular}

Sumber: Data Primer, 2020

Tabel 3. Distribusi Frekuensi Responden Berdasarkan Perilaku Berisiko Tertular Covid-19 di Kota Kendari

\begin{tabular}{lrr}
\hline \multicolumn{1}{c}{ Perilaku Berisiko } & \multicolumn{1}{c}{ N } & \% \\
\hline $\begin{array}{l}\text { Tertular COVID-19 } \\
\text { Bepergian ke Tempat }\end{array}$ & & \\
Ramai & & \\
Ya & 382 & 18,7 \\
Tidak & 1.657 & 81,3 \\
\hline $\begin{array}{l}\text { Pulang Kampung } \\
\text { Ya }\end{array}$ & 949 & 46,5 \\
Tidak & 1.090 & 53,5 \\
\hline $\begin{array}{l}\text { Tidak Menggunakan } \\
\text { Masker }\end{array}$ & & \\
Ya & 340 & 16,7 \\
Tidak & 1.699 & 83,3 \\
\hline $\begin{array}{l}\text { Tidak mencuci tangan } \\
\text { pakai }\end{array}$ & & \\
sabun/handsanitizer & & \\
Ya & 130 & 6,4 \\
Tidak & 1.909 & 93,6 \\
\hline Bepergian ke daerah & & \\
terdapat kasus & & \\
COVID-19 & & \\
Ya & & \\
Tidak & 222 & 10,9 \\
\hline Jumlah & 1.817 & 89,1 \\
\hline Sumber: Data Primer, 2020 & & \\
\hline
\end{tabular}

Distribusi frekuensi responden berdasarkan tindakan berisiko tertular COVID19 dapat dilihat pada Tabel 3. Tindakan berisiko tertular Coivid-19 yang dimaksud adalah bepergian di tempat ramai, pulang kampung ketika diliburkan, tidak mencuci tangan, dan bepergian ke daerah yang terdapat kasus Covid-19. Tabel 3 menunjukkan bahwa dari 2.039 responden, terdapat 382 responden $(18,7 \%)$ yang masih bepergian ke tempat ramai, terdapat 949 responden $(46,5 \%)$ pulang ke kampung masing-masing, terdapat 340 responden $(16,7 \%)$ tidak menggunakan masker, terdapat 130 responden $(6,4 \%)$ tidak mencuci tangan pakai sabun/handsanitizer, dan terdapat 222 responden $(10,9 \%)$ yang bepergian ke daerah yang terdapat kasus COVID-19. Dari kelima tindakan berisiko tertular COVID-19 tersebut, dapat dilihat bahwa pulang ke kampung ketika diliburkan adalah tindakan yang paling banyak dilakukan mahasiswa.

\section{PEMBAHASAN}

COVID-19 merupakan penyakit yang penularan sangat cepat terjadi melalui kontak langsung. Banyak hal yang dilakukan negara di seluruh dunia untuk mencegah penularan penyakit ini. Upaya yang dilakukan pemerintah di seluruh dunia salah satunya melakukan Pembatasan Sosial Berskala Besar (PSBB) di awal terjadi pandemi COVID-19. Pembatasan aktivitas masyarakat dilakukan hampir di semua tempat, baik di tempat ibadah, tempat rekreasi, pusat perbelanjaan bahkan di sekolah-sekolah tidak terkecuali kampus-kampus. Kampus-kampus di Kota Kendari memiliki mahasiswa yang bukan hanya berdomisili di Kendari akan tetapi juga berasal dari berbagai daerah lain. Adanya 
PSBB yang diberlakukan di awal pandemi, mendorong kampus untuk melakukan proses belajar mengajar jarak jauh engan sistem sistem online atau daring (dalam jaringan). ${ }^{8}$ Hal ini dilakukan untuk mencegah terjadinya penularan penyakit COVID-19 di lingkungan kampus.

Mahasiswa merupakan salah satu kelompok berisiko tertular COVID-19. Mengingat proses belajar mengajar yang dilakukan online membuat sebagian mahasiswa harus kembali ke daerah asalnya. Berdasarkan data pada Tabel 1, menunjukkan bahwa mahasiswa di Kota Kendari berasal dari berbagai daerah di Sulawesi Tenggara bahkan ada yang dari luar Sulawesi Tenggara. Dimana sebagian besar wilayah Sulawesi Tenggara terdiri atas kabupaten yang dipisahkan oleh laut seperti Kabupaten Bau-bau, Muna, Konawe Kepulauan, Buton Utara, Bombana, dan Wakatobi. Daerah-daerah tersebut dengan Kota Kendari dipisahkan oleh lautan sehingga otomatis mahasiswa yang kembali ke daerahnya harus menggunakan kapal laut. Selain itu ada yang berasal dari luar Sulawesi Tenggara sehingga ada juga yang harus menempuh perjalanan dengan menggunakan pesawat terbang. Hal ini mengindikasikan bahwa mahasiswa yang melakukan perjalanan ke luar kota baik lewat darat, laut maupun udara memiliki potensi yang besar tertular COVID-19 dan bisa menjadi sumber penularan COVID-19 kepada keluarganya, jika terjadi riwayat kontak dengan yang terinfeksi COVID-19 ketika dalam perjalanan.

Pengetahuan mahasiswa yang diteliti mencakup penyebab, penularan, gejala, dan pencegahan terkait COVID-19 serta kelompok populasi berisiko. Berdasarkan hasil penelitian pada Tabel 2, menunjukkan bahwa sebagian besar mahasiswa di Kota Kendari telah memiliki pengetahuan yang cukup yaitu sebesar 70,1\%. Hal ini sejalan dengan hasil penelitian pada seluruh mahasiswa kesehatan di Indonesia yang menunjukkan bahwa pengetahuan mahasiswa sebagian besar sudah cukup baik (51,3\%). Begitu pula penelitian yang dilakukan di Cina yang bahkan persentasinya lebih besar yang memiliki pengetahuan cukup terkait COVID-19 yaitu mencapai 82,3\%. ${ }^{9}$ Namun kondisi yang bertolak belakang dengan penelitian ini yaitu yang ditemukan dalam penelitian di Bangladesh, bahwa pengetahuan mahasiswa di dalam satu universitas justru didominasi oleh pengetahuan yang buruk terkait COVID-19. ${ }^{10}$ Penularan COVID-19 bisa diminimalisir ketika ada pengetahuan yang cukup terkait penyebab, penularan maupun pencegahan COVID-19. ${ }^{11}$

Selain itu sikap mahasiswa terkait pencegahan penularan COVID-19 juga lebih banyak yang positif $(70,6 \%)$ dibandingkan dengan yang memiliki sikap negatif $(29,4 \%)$. Hal ini berbanding lurus dengan tingginya persentase mahasiswa yang memiliki pengetahuan yang cukup terkait COVID-19. Fakta yang sama juga didapatkan berdasarkan penelitian mahasiswa di Cina dan di Indonesia. Sebagian besar mahasiwa menyatakan sikap setuju terhadap protokol kesehatan yang diberlakukan oleh pemerintah seperti menjaga jarak, menutup mulut ketika bersin atau batuk, menggunakan masker, mencuci tangan, tidak 
bepergian ke tempat ramai, mengisolasi diri saat muncul gejala, serta mendukung pemerintah untuk melakukan lockdown. Seperti halnya penelitian yang dilakukan di Sulawesi Utara menunjukkan bahwa sikap masyarakat Sulawesi Utara terhadap Covid-19 mayoritas memiliki sikap yang positif $(97,8 \%){ }^{12}$ Adanya pengetahuan yang cukup dan sikap positif dibuktikan dengan jumlah mahasiswa yang melakukan tindakan berisiko rendah tertular COVID-19 lebih banyak dibandingkan dengan mahasiswa yang melakukan tindakan berisiko tinggi seperti yang dapat dilihat pada Tabel 2.

Selain diberlakukannya PSBB di masa pandemi, pemerintah juga menghimbau kepada masyarakat umum untuk mematuhi protokol kesehatan untuk mencegah penularan COVID-19. Adapun protokol kesehatan tersebut seperti memakai masker, mencuci tangan menggunakan sabun/handsanitizer, jaga jarak, hindari kerumunan/ tempat ramai, dan tidak melakukan perjalanan ke luar daerah. Protokol kesehatan tersebut menjadi tolak ukur dalam melihat perilaku berisiko tertular COVID-19 pada mahasiswa. Pengetahuan, sikap dan tindakan merupakan tiga hal yang saling berkaitan dalam membentuk perilaku manusia. ${ }^{13}$ Begitu pula halnya pengetahuan, sikap dan tindakan mahasiswa terkait COVID-19 membentuk perilaku mahasiswa selama pandemi COVID19 di Kota Kendari.

Berdasarkan Tabel 3 menunjukkan bahwa tindakan berisiko yang dilakukan mahasiswa masih dalam jumlah yang kecil. Namun dapat dilihat bahwa tindakan berisiko mahasiswa yang paling banyak dilakukan adalah pulang kampong atau kembali ke daerah masing-masing saat diberlakukannya PSBB. Hal ini menjadi salah satu hal yang memperbesar potensi penularan COVID-19. Melihat data pada Tabel 1 bahwa asal mahasiswa banyak yang berasal dari luar Kota Kendari. Adapun wilayah asal mahasiswa yaitu daerah-daerah yang mengharuskan menggunakan transportasi darat, laut maupun udara. Perjalanan yang dilakukan mahasiswa saat pulang kampung menggunakan angkutan publik baik mobil, kapal laut maupun pesawat dapat memperbesar risiko penularan COVID19. Dimana saat awal pandemi, Dinas Perhubungan Provinsi Sultra memberlakukan pembatasan penggunaan sarana transportasi darat, laut, maupun udara dengan tujuan keluar dan/atau masuk wilayah zona merah penyebaran COVID-19 sesuai Permenhub Nomor 18 Tahun 2020 tentang Pengendalian Transportasi dalam Rangka Pencegahan Penyebaran COVID-19. ${ }^{14}$ Berdasarkan data dari Gugus Tugas COVID-19 Provinsi Sultra, wilayah dengan status zona merah COVID-19 yakni Kota Kendari, Kabupaten Konawe Selatan (Konsel), Konawe, Kolaka, Kolaka Utara (Kolut) dan Muna. Sementara kabupaten lainnya berstatus kuning dan hijau serta hitam di Wakatobi. Adanya mahasiswa yang keluar kota Kendari untuk kembali saat pandemi cukup berisiko, namun dengan bekal pengetahuan yang cukup dan sikap yang positif akan memperkecil risiko penularan jika didukung dengan pelaksanaan protokol kesehatan yang ketat. 


\section{KESIMPULAN DAN SARAN}

Berdasarkan hasil penelitian dapat ditarik kesimpulan bahwa sebagian besar mahasisiwa di Kota Kendari memiliki pengetahuan yang cukup, sikap positif dan melakukan tindakan berisiko cukup rendah, Walaupun ada sebagian kecil responden yang masih melakukan perilaku yang berisiko tertular COVID-19, namun dapat disimpulkan bahwa gambaran perilaku (pengetahuan, sikap, dan tindakan) mahasiswa COVID-19 selama pandemi di Kota Kendari sudah cukup baik.

Berdasarkan kesimpulan di atas, maka diharapkan kepada pemerintah dan dinas kesehatan untuk terus-menerus menghimbau masyarakat untuk mematuhi protokol kesehatan dan dapat memberi sanksi bagi masyarakat yang tidak mematuhi protokol kesehatan. Bagi mahasiswa dan juga masyarakat Kota Kendari dapat meningkatkan perilaku hidup bersih dan sehat dan patuh dalam menerapkan protokol kesehatan. Bagi peneliti selanjutnya dapat melakukan analisis hubungan lebih lanjut mengenai pengetahuan dan sikap dalam hubungannya dengan tindakan pencegahan penularan COVID-19.

\section{UCAPAN TERIMA KASIH}

Penulis menyampaikan ucapan terima kasih kepada seluruh mahasiswa di Kota Kendari dan seluruh pihak yang telah bersedia menjadi responden dan mendukung terlaksananya penelitian ini.

\section{DAFTAR PUSTAKA}

1. Güner R, Hasanoğlu , Aktaş F. COVID19: Prevention and control measures in community. Turk J Med Sci. 2020;50(3):571.

2. Perhimpunan Dokter Paru Indonesia. Pneumonia COVID-19: Diagnosis dan Penatalaksanaan di Indonesia. Jakarta; 2020.

3. World Health Organization. Coronavirus Disease (COVID-19). Geneva; 2020.

4. Satuan Tugas COVID-19. Coronavirus Disease (COVID-19). Jakarta; 2020.

5. Shereen MA, Khan S, Kazmi A, Bashir N, Siddique R. COVID-19 infection: Origin, Transmission, and Characteristics of Human Coronaviruses. J Adv Res. 2020;24:91-98.

6. Awasthi A, Vishwas S, Corrie L, Kumar R, Khursheed R, Kaur J, et al. Outbreak of Novel Corona Virus Disease (COVID-19): Antecedence and Aftermath. Eur J Pharmacol. 2020;884:173381.

7. Harapan H, Itoh N, Yufika A, Winardi W, Keam S, Te H, et al. Coronavirus Disease 2019 (COVID-19): A literature Review. J Infect Public Health. 2020;13(5):667-673.

8. Kemdikbud RI. Keputusan Menteri Pendidikan dan Kebudayaan Republik Indonesia Nomor 719/P/2020 Tentang Pedoman Pelaksanaan Kurikulum Pada Satuan Pendidikan Dalam Kondisi Khusus. Jakarta; 2020.

9. Peng Y, Pei C, Zheng Y, Wang J, Zhang K, Zheng Z, Zhu P. A Cross-Sectional Survey of Knowledge, Attitude and Practice 
Associated with COVID-19 among Undergraduate Students in China. BMC Public Health. 2020;20(1):1-8.

10. Wadood MA, Mamun AS, Rafi MA, kamrul Islam M, Mohd S, Lee LL, Hossain MG. Knowledge, Attitude, Practice and Perception Regarding COVID-19 among Students in Bangladesh: Survey in Rajshahi University. medRxiv. 2020 Jan 1.

11. Usman S, Budi S, Sari DNA. Pengetahuan dan Sikap Mahasiswa Kesehatan tentang Pencegahan COVID-19 di Indonesia. Jurnal Ilmu Keperawatan dan Kebidanan. 2020;11(2):258-264.

12. Sembiring EE, Meo MLN. Pengetahuan dan Sikap Berhubungan dengan Resiko Tertular Covid-19 pada Masyarakat Sulawesi Utara. NERS: Jurnal Keperawatan. 2020;16(2):75-82.

13. Notoatmodjo S. Ilmu Perilaku Kesehatan. Jakarta: Rineka Cipta. 2014.

14. Kemenhub RI. Permenhub Nomor 18 Tahun 2020 tentang Pengendalian Transportasi dalam Rangka Pencegahan Penyebaran Covid-19. Jakarta; 2020. 